\title{
Ecological correlates and short-term effects of relocation of a rare epiphytic orchid after Hurricane Georges
}

\author{
Raymond L. Tremblay ${ }^{1,2, *}$ \\ ${ }^{1}$ Department of Biology, University of Puerto Rico, Humacao, Puerto Rico 00791, USA \\ ${ }^{3}$ Center for Applied Tropical Ecology and Conservation, PO Box 23341, \\ University of Puerto Rico, Rio Piedras, Puerto Rico 00931, USA
}

\begin{abstract}
In the Caribbean, hurricanes are common and can result in the loss of a large component of the epiphytic community as a result of felled tress; the re-establishment of such epiphytic communities is a slow process. Consequently, it is important to determine whether the management of endangered epiphytic plants could include the relocation of individuals from felled to standing trees after hurricanes. If plants can be successfully re-established on standing trees, can new viable populations be established? In this study, ecological correlates and the immediate effect of relocation of a rare endangered epiphytic orchid post Hurricane Georges are examined. Seedlings, juveniles and adults of the protected orchid Lepanthes eltoroensis Stimson were relocated from felled trees onto standing trees along a $5 \mathrm{~km}$ stretch of elfin forest and surveyed after 6 and $12 \mathrm{mo}$. Plants were relocated onto trees that had or were adjacent to trees with con-specific orchids. The effect of this manipulation on survivorship and growth of orchids was evaluated, and the effect of relocating the orchids on occupied and un-occupied phorophytes was compared. L. eltoroensis is preferentially distributed at elevations of 800 to $900 \mathrm{~m}$ above sea level, and no preference for specific species of trees was observed. Orchid population size was not correlated with percent moss cover on standing trees. Relocation of orchids from felled trees to standing trees as a management tool for this species was positive, as most individuals ( $73 \%$ ) survived the first year; however, this was significantly less than non-relocated plants on standing trees (94\%). Management should include re-locating orchids as soon as possible after a hurricane to maximize individual survivorship of this endangered species.
\end{abstract}

KEY WORDS: Altitudinal gradient · Conservation · Puerto Rico · Population relocation · Survivorship · Orchidaceae $\cdot$ Lepanthes eltoroensis

\section{INTRODUCTION}

Hurricanes can have a dramatic effect on communities and individuals species (Lodge \& McDowell 1991, Fernández \& Fetcher 1991, You \& Petty 1991). The effect of hurricanes on epiphytes communities can be remarkable, often resulting in partial to complete loss of this component of biodiversity (Rodríguez-Robles et al. 1990, Migenis \& Ackerman 1993).

In situ management of epiphytic flora requires consideration and understanding of the relative importance of a number of on-site variables that may influ- ence persistence. Growth rate, and consequently population size, is influenced by a number of environmental variables in plants in general (Valladares et al. 2006, Smith \& Sibly 2008) and in orchids in particular (Agosto-Pedroza \& Tremblay 2003, Fernández et al. 2003, Ruiz-Canino et al. 2007). Epiphytic plants may be influenced by the specificity of the tree host species, as is the case with the small epiphytic orchid Lepanthes caritensis, which is found on only 1 species of tree (Tremblay et al. 1998); however, in general orchid species are generally non-host specific (Zimmerman \& Olmstead 1992, Ackerman et al. 1989). 
The Luquillo Mountain babyboot orchid Lepanthes eltoroensis has a preference for a specific area of the bole of trees; almost all individuals are found on the bole up to approximately $3 \mathrm{~m}$ and have a preference for the west-northwest region of the bole (Tremblay \& Velazquez-Castro in press). This phenomenon is likely a result of the dominant wind coming form the opposite direction.

In order to evaluate the best way to manage for rare and endangered epiphytic plants after hurricanes, to determine whether relocating orchids from fallen trees to standing hosts an effective management strategy and to increase our knowledge about the basic niche preference of Lepanthes eltoroensis, we relocated individuals from felled trees in the Yunque National Forest in Puerto Rico to standing host trees. Specifically, the following questions were evaluated: (1) Is L. eltoroensis phorophyte specific? (2) Is there an altitudinal preference for the species distribution? (3) What is the extent of moss cover on host tree species? (4) Is there a relationship between light availability and population size? (5) What is the mean diameter at breast height of host trees? (6) What is the effect of relocating plants from fallen to standing trees on growth and survivorship? (7) Do plants need to be relocated onto trees where orchids are present or can new populations be created?

\section{MATERIALS AND METHODS}

Species. Lepanthes eltoroensis (Fig. 1) is limited in distribution to the Yunque National Forest and protected by federal law. The orchid is epiphytic and distributed mostly along the El Toro and Tradewind trails and on Mount Cacique. This survey is limited to 87 populations (orchids on a single tree are considered a population, as shown from spatial and genetic studies; Tremblay 1997, Tremblay \& Ackerman 2001,2003 ) found along the 2 connecting walking trails. L. eltoroensis plants are prostrate, with slender stems bearing a solitary leaf (up to $3.8 \mathrm{~cm}$ long) subtending 1 to a few inflorescences, capable of producing many minute flowers $(<8 \mathrm{~mm}$, Ackerman 1995). Plants are obligate cross-pollinated and protandrous (Tremblay et al. 2006). Reproductive success in this orchid, as in most orchids, is pollinatorlimited (Tremblay et al. 2005). Previous studies have shown that limited gene flow is present among groups of individuals on trees, even when physically close (Tremblay \& Ackerman 2001), which is typical of many orchids
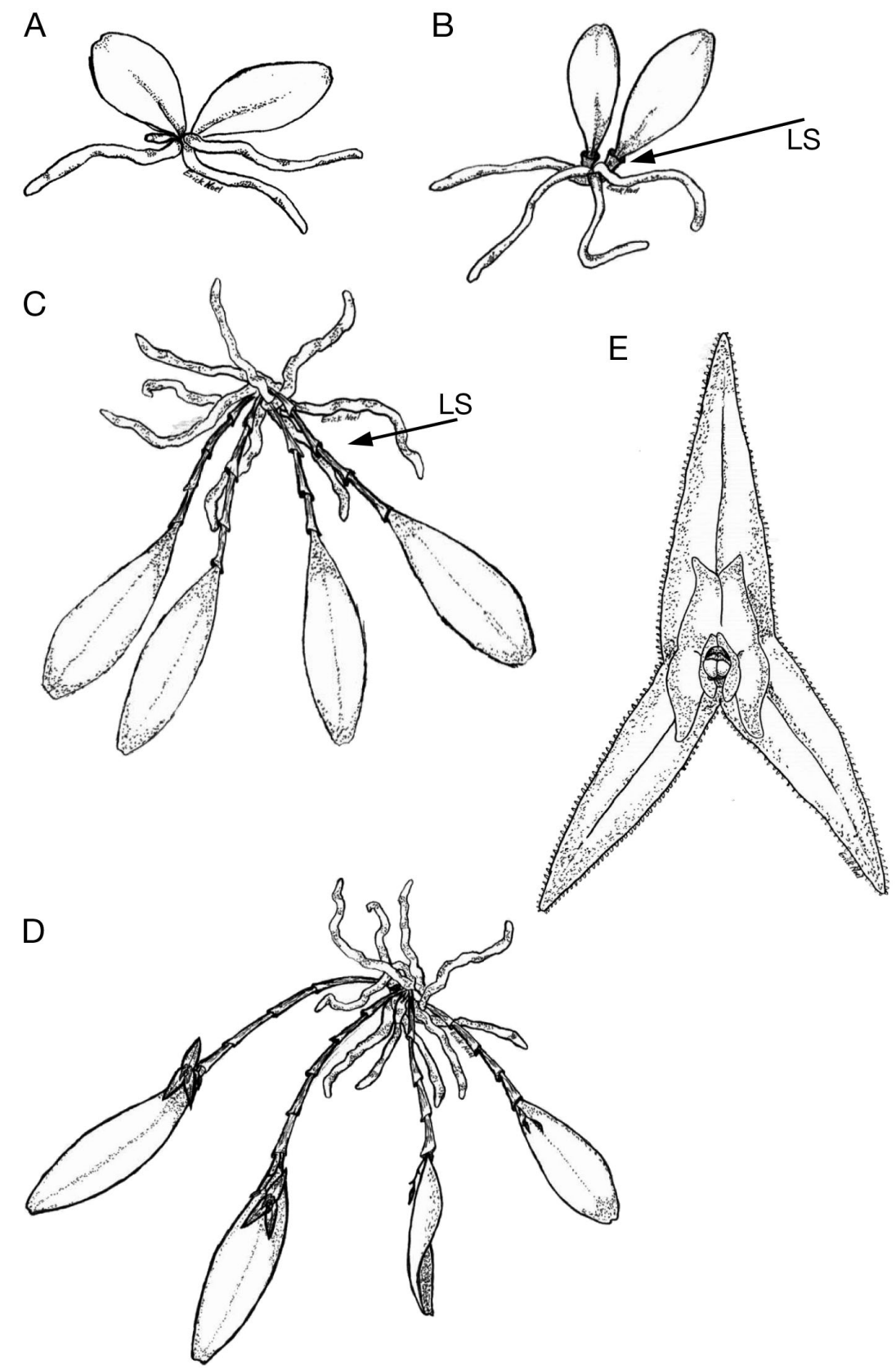

Fig. 1. Lepanthes eltoroensis Stimson. (A) Seedling (note the absence of lepanthiform sheaths on petiole). (B) Juvenile (petiole with lepanthiform sheaths, LS, indicated by an arrow). (C) Adult without inflorescence. (D) Adult with inflorescence and flowers. (E) Flower. Drawing by Erick Noel Bermúdez Carambot 
(see Tremblay \& Ackerman 2003, Tremblay et al. 2005). Fruits produce many seeds (over 3000 in a related species, L. rupestris, R. L. Tremblay unpubl. data) and require a mycorrhizal association for germination and survival until plants start photosynthesis. The pollinator of $L$. eltoroensis is unknown, but black-winged fungus gnats are known pollinators of Lepanthes elsewhere (Blanco \& Barboza 2005). Previous studies have shown that the mean population size is small (11.6) and that the mean crowding index is high (47.6) with a mean distance of $38.6 \mathrm{~m}$ between populations (Tremblay 1997); the spatial distribution of populations is usually not normally distributed. The estimated life span is short (mean $5.2 \mathrm{yr}$ ), and the length of different life stages varies considerably, with median adult stage being longer than that of seedling and juvenile stages (Tremblay 2000). Plants are likely to attain maturity after approximately 2 yr; however, in a related species (L. rupestris), plants can flower in the laboratory in $>1 \mathrm{yr}$.

Study area. The study was carried out along a ca. $5 \mathrm{~km}$ section of 2 continuous trails, the El Toro and Tradewind trails, in the northern area of El Yunque National Forest. The trails meander in an east-west direction between highways 191 and 186, mainly in elfin forest type habitat, but also through palm-dominated forest in the mid elevations. The section surveyed fluctuated between 650 and $1050 \mathrm{~m}$ in elevation. Mean annual precipitation in the elfin forest is $4.2 \mathrm{~m}$ (at the nearby Pico del Este); the rainy season centers around October and the dry season around March (Wang et al. 2003).

Data collection. Hurricane Georges passed over Puerto Rico in September 1998. As a result of high winds, many trees sustaining orchids fell. A total of 178 orchids were relocated $1.5 \mathrm{yr}$ after the hurricane from fallen trees to standing trees; all plants were removed with as much bark as possible and 94 of the collected plants were relocated to the next nearest occupied phorophyte (having conspecific plants), while 84 were relocated on an adjacent non-occupied tree of the same species. Fallen trees with orchids were not surveyed after removing the orchids as the US Forest Service removed these from the trails.

As a partial control for the effects of displacement of these individuals, all conspecific plants present on the relocated trees were censused. The unbalanced experimental design included 3 treatments: (1) plants removed from fallen trees and relocated on occupied standing trees; (2) plants removed from fallen trees and relocated on unoccupied standing trees; and (3) un-relocated plants of the occupied trees. Because this species is listed as critically endangered, manipulation was limited to plants that had to be relocated.

In this study, the short-term effects (1 yr) are evaluated. Lepanthes eltoroensis were censused on 87 trees (fallen and standing) in September 2000 (relocation of plants), March 2001 and September 2001. The orchids were present on the bole and the buttressed roots of the tree and rarely on branches. Within each tree all orchid plants were permanently identified and classified into 1 of 3 life cycle stages (this being repeated after $6 \mathrm{mo}$ ), according to the following rules: (1) seedlings were small plants without a petiole (lepanthiform sheets $=$ ramicaul) on any stem; (2) juveniles were individuals with at least 1 lepanthiform sheath on the petiole without evidence of past or current reproduction; (3) adults were individuals currently reproductive (have active inflorescences) or having the potential for reproduction. Plants considered to have the potential to reproduce carried dry but persistent inflorescences from a previous flowering event. Dried inflorescences can persist on the plant for years after they have been active.

Moss cover was estimated as the percent cover of all types of bryophytes surrounding the individual orchids around the whole bole of the tree. Light availability was estimated in the field with a spherical crown densiometer as percent leaf cover, and was estimated above the centroid of the orchid population for each population. Moss cover was evaluated in $10 \%$ increments from 0 to $100 \%$.

Populations surveyed. All trees along the trails were surveyed for the presence of orchids and the species of trees with Lepanthes eltoroensis were noted if possible (some phorophytes were dead and still standing or felled, and thus could not be identified to species). Standing trees were surveyed up to $2 \mathrm{~m}$ within the forest on either side of the trail when topography permitted, extremely rarely were orchids observed higher than $2 \mathrm{~m}$ above the trail floor. The light environment was measured (see 'Data collection' above) at 87 populations.

Statistical methods. Statistical tests employed to test hypotheses varied based on the data used and whether data followed normal distribution and equality of variance. In all cases, parametric tests were used when the assumptions of normality and equality of variance were met and non-parametric tests were used when otherwise. Testing of normality was performed with the Kolmogorov-Smirnov test (Sokal \& Rohlf 1981). Differences among time period of continuous characters were tested with paired $t$-test: between 2 groups either the Student's $t$-test or MannWhitney test was used; among multiple groups the Kruskal-Wallis non-parametric test was used. Contingency table type tests and Fisher's exact test for chisquared type analysis were analyzed using Monte Carlo simulations using the following web program: www.physics.csbsju.edu/stats/contingency_NROW_ NCOLUMN_form.html. The mean and standard devi- 
ation are shown, but were not used for testing hypotheses based on parametric tests, as most of the data do not follow normal distribution, and equality of variance is rarely met.

Ecological correlates (light availability, moss cover and altitude) of occupied phorophytes and population size were analyzed using linear and quadratic equations.

All tests, except the contingency tables, were performed using the statistical program JMP (v. 5.1.1). Count data (number of individuals) were square-root transformed and continuous variables (length and diameter at breast height, DBH) were log-transformed prior to analyses to reduce heteroscedasticity.

\section{RESULTS}

\section{General observations}

The original survey found 211 orchids on standing trees and 192 orchids on fallen trees, for a total 403 relocated orchids. Most of the individuals found on fallen trees were adults $(76.0 \%)$, while seedlings comprised $18.8 \%$ and juveniles $5.2 \%$; proportionally fewer adults were found on standing trees $(55.6 \%)$, while juveniles represented $37.9 \%$ and seedlings $6.2 \%$. Differences in life stages among standing and fallen trees was significant (chi-squared test, 19.59, $\mathrm{p}<0.0001)$. Fallen trees do not appear to be an appropriate environment for the early stages. All orchids found on fallen trees were on the undersides, only dried and dead orchids were found on the exposed sides of trees.

\section{Host specificity and hurricane tree damage}

Along the 2 trails at the beginning of the survey (September 2000) 87 trees of varying species were observed with Lepanthes eltoroensis: Ocotea spathulata Mez, Micropholis garciniifolia Pierre, Clusia clusioides (Griseb.) D'Arcy, Chrysophyllum bicolor Poir., Tabebuia rigida Urb., Cordia borinquensis Urb., Didymopanax morototoni (Aubl.) Decne. \& Planch., Croton poecilanthus Urb., Eugenia borinquensis Britton, Calycogonium squamulosum Cogn., Laplacea portoricensis (Krug \& Urb.) Dyer, Clusia rosea Jacq. and the palm Prestoea acuminata (Willd.) H. E. Moore. A total of $24 \%$ of the trees with orchids were found lying across or along the trail, presumably felled by the hurricane. Unfortunately, because the first survey was done $1.5 \mathrm{yr}$ after the hurricane, it could not be determined whether some species of host trees were more likely to be effected by the hurricane.

\section{Tree species and orchid population size}

The difference between the number of individual orchids on different tree species was not significant (Kruskal-Wallis $H$ corrected for ties $=7.905, \mathrm{p}=0.25$ ). Some species of trees were rarely found with orchids on their boles; and thus the sample size (number of tree species with orchids) was low. Consequently, in this analysis only tree species found three or more times with orchids were included (Table 1). Variation in orchid population size among trees is very high and shown by the high SE.

\section{Altitude and orchid population size}

Most populations of Lepanthes eltoroensis were found at altitudes of approximately 750 to $950 \mathrm{~m}$. The frequency distribution is not different from a normal distribution (Kolmogorov-Smirnov test for normality, chi-squared 5.851, $p=0.107, N=67$ ), thus suggesting that the preferred range is between 800 and $975 \mathrm{~m}$ (Fig. 2).

The number of individuals per phorophyte is not significantly correlated with altitude as defined by a simple linear regression ( $p>0.54$ ) or as a quadratic regression on the square root of total number of orchids per tree. The lower range of the surveyed altitude (800 to $850 \mathrm{~m})$ was where the largest populations were observed (Fig. 3)

\section{Condition of plants at the beginning of the experiment}

Comparison of orchids on fallen trees and those observed on standing trees suggest that the number of leaves, percent pollinia removal per flower (in most orchids pollen is presented in packets) and fruit production, the number of inflorescences, and number of

Table 1. Lepanthes eltoroensis Stimson. Number of individuals found on the most common phorophytes. $\mathrm{N}=$ number of trees, mean $=$ mean number of orchids per tree

\begin{tabular}{|lrrr|}
\hline Species & N & Mean & SE \\
\hline Cecropia pelata L. & 3 & 75.7 & 29.4 \\
Chrysophyllum bicolor Poir. & 6 & 13.5 & 2.6 \\
Clusia clusioides (Griseb.) D'Arcy & 15 & 20.7 & 5.1 \\
Micropholis garciniifolia Pierre & 11 & 16.6 & 3.5 \\
Ocotea spathulata Mez. & 5 & 31.4 & 11.0 \\
Prestoea acuminata (Willd.) & 8 & 30.8 & 11.3 \\
H. E. Moore & & & \\
Tabebuia rigida Urban & 3 & 11.0 & 5.0 \\
& & & \\
\hline
\end{tabular}




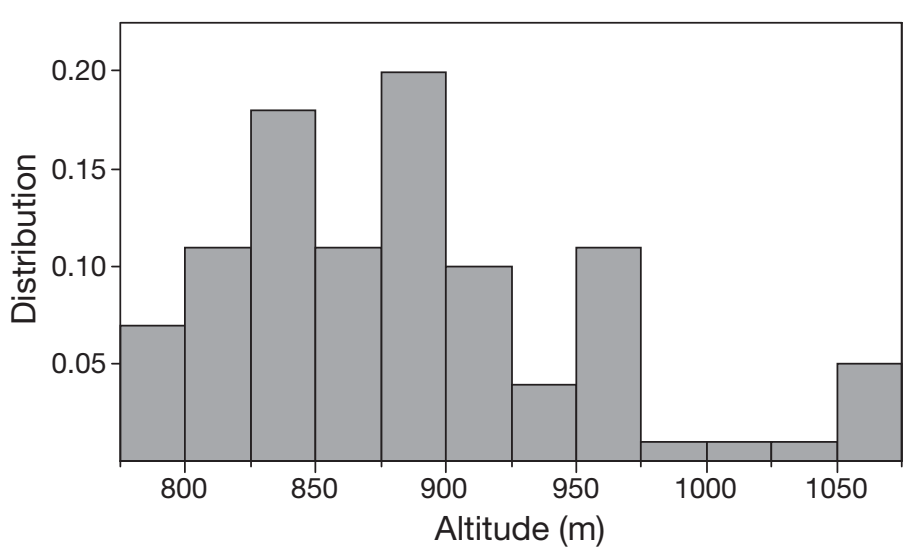

Fig. 2. Altitudinal distribution (above sea level in meters) of tree host supporting the endangered orchid Lepanthes eltoroensis along the Tradewind and El Toro trail

open flowers per plant was not significantly different between standing and fallen trees (Table 2). The only variable that came close to being significantly different was the number of open flowers. In spite of this trend, the number of individuals found on fallen trees was significantly lower then on standing trees (fallen trees: $4.4 \pm 0.87$ [mean $\pm \mathrm{SE}$ ], $\mathrm{n}=21$; standing tree $10.7 \pm$ $1.41, \mathrm{n}=63, t$-test $=3.80, \mathrm{df}=81.5, \mathrm{p}=0.0003$ ).

\section{Light availability}

The amount of light was lower around standing trees than fallen trees (percent leaf cover: fallen trees, $26.7 \pm$ $5.0, \mathrm{n}=21$; standing trees, $45 \pm 2.8, \mathrm{n}=66$; $t$-test, unequal variance $t=2.886, \mathrm{p}=0.007$ ). Even so, the amount of light does not appear to be a good predictor of the number of orchids when analyzed using simple linear or quadratic regressions. Yet the range of populations with a 40 to $60 \%$ shadow was dominant and can be seen when viewed with a non-parametric (quantile density contours) (Fig. 4).

Table 2. Lepanthes eltoroensis Stimson. Vegetative characteristics and reproductive potential of individuals on standing $(\mathrm{n}=212)$ and fallen trees $(\mathrm{n}=192)$ prior to relocation. Mean \pm SE (median value in parenthesis) are shown. Tests performed with Mann-Whitney $U$-test with ties

\begin{tabular}{|lccc|}
\hline Variable & Plants on & Plants on & Mann-Whitney \\
& fallen trees & standing trees & U-test \\
\hline Number of leaves & $3.5 \pm 0.11(3)$ & $3.3 \pm 0.11(3)$ & $\mathrm{p}=0.26$ \\
Number of inflorescences & $1.5 \pm 0.07(2)$ & $1.0 \pm 0.06(1)$ & $\mathrm{p}=0.29$ \\
Number of flowers & $0.30 \pm 0.05(0)$, & $0.17 \pm 0.04(0)$ & $\mathrm{p}=0.06$ \\
& 35 flowers & 57 flowers & \\
Percent pollinia removal & $0.93 \pm 0.01(1)$ & $0.95 \pm 0.01(1)$ & $\mathrm{p}=0.16$ \\
Number of fruits & $0.014 \pm 0.006(0)$ & $0.005 \pm 0.007(0)$ & $\mathrm{p}=0.36$ \\
& Total fruits $=3$ & Total fruits $=2$ & \\
\hline
\end{tabular}

\section{Moss cover}

The amount of moss cover was significantly different among trees that were standing and felled. Felled trees had only $34 \pm 5.2 \%$ moss cover, while standing trees had $54 \pm 3.3 \%$ moss cover ( $t$-test, unequal variance $t=$ $3.32, p=0.002)$. Neither linear nor quadratic functions in the percent moss cover on the occupied phorophyte was explicative of the total population size (Linear regression: $F_{1,80}=0.008, \mathrm{p}=0.93$; quadratic regression: $\left.F_{2,79}=0.09, \mathrm{p}=0.91\right)$.

Evaluation of the correlation between moss cover and number of orchids on standing trees again shows no clear linear or quadratic patterns (Linear regression: $F_{1,45}=1.166, \mathrm{p}=0.28$; quadratic regression: $F_{2,44}$ $=1.053, \mathrm{p}=0.38)$. A non-parametric density contour map does show a clearer influence of moss density on orchid population size; orchids appear to be more frequently present when the bole of trees had between 40 and $90 \%$ moss cover.

\section{Effect of removal and relocation of Lepanthes eltoroensis}

Leaf production after 6 and 12 mo

Both relocated and non-relocated plants lost leaves between August 2000 and February 2001 (paired $t$ test, df 365, $t=6.366, \mathrm{p}<0.0001$; Relocated $=-0.574 \pm$ $0.095, \mathrm{~N}=164$; Non-Relocated $=-0.267 \pm 0.086, \mathrm{~N}=$ 202). In the subsequent 6 mo interval (February to August 2001) there was no significant increase or decrease and growth was similar among removed and Non-Relocated orchids (paired $t$-test, df 375, $t=0.697$, $\mathrm{p}=0.49$; Relocated $=-0.042 \pm 0.074, \mathrm{~N}=166$; NonRelocated $=0.095 \pm 0.067, \mathrm{~N}=210$ ).

The number of leaves gain (or loss) on plants relocated to occupied or non-occupied host trees during the first 6 mo was significantly different, as orchids relocated to non-occupied trees lost significantly more leaves than those transferred to occupied trees (Non-Occupied phorophyte: $-0.474 \pm 0.190, \mathrm{n}=$ 78; Occupied phorophyte: $-0.389 \pm$ $0.063, \mathrm{n}=288$; paired $t$-test, df $365, \mathrm{p}=$ 0.0001). However, in the subsequent 6 mo the number of leaves on plants relocated to unoccupied trees had a general increase (although not significant) and no significant differences were noted among the sites of growth (mean change, Non-Occupied phorophyte: $0.13 \pm 0.12$; Occupied phorophyte: 0.01 \pm 0.05 ; paired $t$-test, df $375, \mathrm{p}=0.49$ ). 


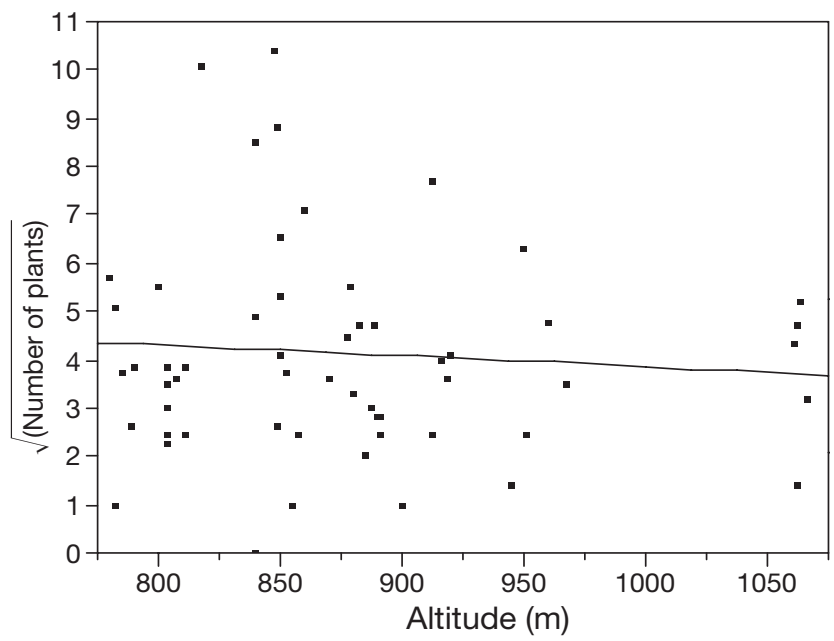

Fig. 3. Lepanthes eltoroensis Stimson. Square root total population size (adults, juveniles and seedlings) on trees at varying elevation above sea level

Survival of plants after 6 and 12 mo

The likelihood of survival or death of individuals of the different stages (seedling, juvenile and adults) of Lepanthes eltoroensis after 6 mo was not significantly different, except during second half of the survey period for plants that were not relocated (Table 3).

Plants were more likely to die if they were removed and relocated than when they were not relocated. The probability of death of non-relocated plants was $6.2 \%$, while for relocated plants it was $27.0 \%$. The effect of manipulation was still seen after 1 yr (Table 4). However, for removed plants the probability of death was similar whether plants were relocated to occupied or unoccupied phorophytes (Table 5).

\section{Flower production after 6 and 12 mo}

Number of flowers produced is one of the indicators of plant health and potential reproductive success. Plants relocated to occupied and unoccupied host trees had the same quantity of flower production after 6 and 12 mo (6 mo, median test, normal approximation, $\mathrm{Z}=-0.5234$,
Table 4. Lepanthes eltoroensis Stimson. Effect of plant removal or non-removal on survival after 6 and 12 mo, Fisher's Exact test

\begin{tabular}{|lcccc|} 
& \multicolumn{2}{c}{6 mo } & \multicolumn{2}{c|}{12 mo } \\
& Alive & Dead & Alive & Dead \\
\hline Not Removed & 207 & 2 & 225 & 3 \\
Removed & 172 & 20 & 178 & 9 \\
& $\mathrm{p}<0.001$ & & $\mathrm{p}=0.034$ \\
\hline
\end{tabular}

Table 5. Lepanthes eltoroensis Stimson. Effect of relocation on survivorship to occupied or non-occupied trees, Fisher's Exact test

\begin{tabular}{|lcccc|}
\hline & \multicolumn{2}{c}{6 mo } & \multicolumn{2}{c|}{12 mo } \\
& Alive & Dead & Alive & Dead \\
\hline Occupied, Relocated & 91 & 13 & 94 & 6 \\
Not Occupied, & 81 & 7 & 84 & 3 \\
Relocated & & & & \\
& & & & \\
& & & & \\
& & & & \\
\hline
\end{tabular}

$\mathrm{p}=0.60 ;$ Occupied $=0.324 \pm 0.073, \mathrm{~N}=105$; Not Occupied $=0.261 \pm 0.079, \mathrm{~N}=88 ; 12 \mathrm{mo}$, median test, normal approximation, $\mathrm{Z}=-0.3812, \mathrm{p}=0.70 ;$ Occupied $=0.181 \pm$ $0.048, \mathrm{~N}=94$; Not Occupied = $0.143 \pm 0.051, \mathrm{~N}=84$ ).

However, relocated plants had a slightly higher flower production after 6 mo than non-relocated plants, although not significantly; this pattern was consistent after 12 mo where no difference in flower production was noted (6 mo, median test, normal approximation, $\mathrm{Z}=1.906, \mathrm{p}=0.057$; Relocated $=0.296 \pm 0.045$, $\mathrm{N}=193 ;$ Non-Relocated $=0.166 \pm 0.043, \mathrm{~N}=211 ; 12$ mo, median test, normal approximation, $\mathrm{Z}=1.560, \mathrm{p}=$ 0.19 ; Relocated $=0.163 \pm 0.032, \mathrm{~N}=178$; Non-Relocated $=0.113 \pm 0.029, \mathrm{~N}=221$ )

\section{Number of fruits produced}

Fruit production was not related to plants being relocated (Mann-Whitney $U$-test, Tied p-value = 0.60; Removed, mean percent fruit set $\pm \mathrm{SD}=0.013$ $\pm 0.113, \mathrm{~N}=234 ;$ Not Removed $=0.008 \pm 0.091$, $\mathrm{N}=359$ ).

Table 3. Lepanthes eltoroensis Stimson. Probability of survival after 6 and 12 mo of seedlings, juveniles and adults. All tests done by Monte Carlo simulation for contingency table type analysis

\begin{tabular}{|c|c|c|c|c|c|c|c|c|c|c|c|c|}
\hline & \multicolumn{4}{|c|}{ Occupied-Not Relocated } & \multicolumn{4}{|c|}{ Occupied-Relocated } & \multicolumn{4}{|c|}{ Not Occupied-Relocated } \\
\hline & \multicolumn{2}{|c|}{$6 \mathrm{mo}$} & \multicolumn{2}{|c|}{$12 \mathrm{mo}$} & \multicolumn{2}{|c|}{$6 \mathrm{mo}$} & \multicolumn{2}{|c|}{$2 \mathrm{mo}$} & \multicolumn{2}{|c|}{$6 \mathrm{mo}$} & \multicolumn{2}{|c|}{$12 \mathrm{mo}$} \\
\hline & Alive & Dead & Alive & Dead & Alive & Dead & Alive & Dead & Alive & Dead & Alive & Dead \\
\hline Seedling & 13 & 0 & 7 & 2 & 8 & 0 & 3 & 0 & 1 & 1 & 3 & 0 \\
\hline Juvenile & 79 & 1 & 77 & 0 & 13 & 5 & 18 & 2 & 17 & 1 & 13 & 0 \\
\hline \multirow[t]{2}{*}{ Adult } & 115 & 1 & 139 & 1 & 70 & 8 & 73 & $\overline{4}$ & 63 & 5 & 68 & 3 \\
\hline & \multicolumn{2}{|c|}{$\mathrm{p}=0.90$} & \multicolumn{2}{|c|}{$\mathrm{p}<0.001$} & \multicolumn{2}{|c|}{$p=0.07$} & \multicolumn{2}{|c|}{$p=0.67$} & \multicolumn{2}{|c|}{$\mathrm{p}=0.71$} & \multicolumn{2}{|c|}{$\mathrm{p}=0.70$} \\
\hline
\end{tabular}




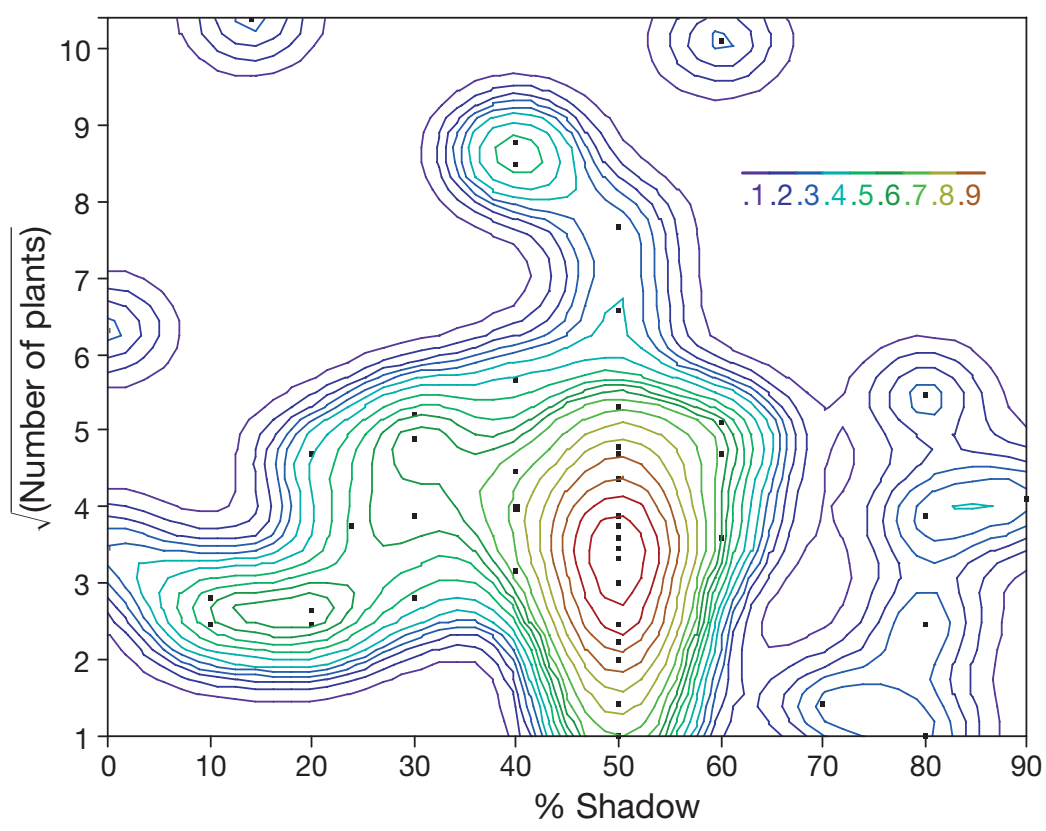

Fig. 4. Lepanthes eltoroensis Stimson. Distribution of populations as a function of percent light availability and square root of population size. Nonparametric quantile density contours are shown. Most phorophytes where orchids were observed had $>20 \%$ but $<70 \%$ shadow, and the largest range of orchid population sizes was in the range of $40-60 \%$ shadow

usually very resilient to transplantation to different substrate, at least based on orchid growers' experience. Leaf production, flower production, pollinaria removal and fruit set were all similar for re-located plants, with no significant differences observed between orchids relocated to occupied or non-occupied hosts. Still, relocation does cause a stress to plants and these have a higher probability of dying. Consequently, plants should not be transplanted if they do not need to be. In general epiphytes located on trees that subsequently fall are unlikely to persist for a long time; in addition, such sites usually becomes inappropriate for population growth. Moreover, what relative importance the individuals on the fallen trees have on the gene pool as a result of pollen seed dispersal in unknown.

The increase in number of flowers on felled trees could potentially be a result of more available light (due to the opening of the canopy). Plants were almost exclusively found on the part of the tree that was in the middle of the trail, where light conditions might have favored flower pro-

Fruit production was furthermore not related to plants being relocated to Occupied or Not Occupied phorophytes (Mann-Whitney $U$-test, Tied $\mathrm{p}$ value = 0.32; Occupied $=0.007 \pm 0.084, \mathrm{~N}=234$; Not Occupied $=0.022 \pm 0.147, \mathrm{~N}=91$ ).

\section{DISCUSSION}

Post-hurricane loss of Lepanthes is likely a result of death due to orchids on fallen trees being exposed directly to the sun and drying winds as result of opening of the canopy; consequently, most of the orchids still alive on fallen trees were on the underside of the bole. It is possible that loss could also have been caused directly by the strong wind during the hurricane, i.e. orchids being forcibly blown off the bole, however this is unlikely to be common, as these plants are small and offer very little resistance to the wind, being very pliable plants. In addition, rarely were leaf stems found without the leaf, suggesting that these were not torn off by the wind.

In general the results are positive for promoting relocation and management of this species. Plants can be relocated successfully from felled trees to a new host and it is irrelevant whether or not orchids are present on that new host. The phorophyte selected does not appear to need other orchids to be present. Orchids are duction. Orchids on fallen trees had similar numbers of fruits to those on standing trees. This suggests that the pollinators do not appear to have a preferential habitat. The cause of differential flower production could be from other environmental factors in addition to light conditions (i.e. nutrient availability, water availability). Zimmerman (1991) has observed in another epiphytic orchid, Catasetum viridiflavum, resource availability from dying or dead trees can have an effect on growth and flowering.

Pollinaria removal and fruit set are highly skewed to the left (data mostly zeros), consequently it is difficult to determine if any effects are present between the different habitats. A total of 3 pollinaria removals and 2 fruits were observed on plants relocated to non-occupied phorophytes. This suggests that the pollinators are present and are pollinating the flowers (these do not automatically self pollinate) and are likely to be protandrous as shown in other Lepanthes species from Puerto Rico (Tremblay et al. 2006).

The low fruit set observed in these populations of orchids is not abnormal for this species or others from the same genus (Tremblay et al. 2005). In previous studies, similar low fruit set was observed (Tremblay et al. 1998, Tremblay \& Ackerman 2001, Tremblay 2003).

It is important to specify that Lepanthes eltoroensis seedlings cannot be distinguished from seedlings of the other Lepanthes species; in spite of this, most pho- 
rophytes only had individuals of $L$. eltoroensis and rarely have the 2 conspecific species L. Woodburyana and $L$. dodiana been found on the same tree. The number of seedlings counted represents the approximate number of seedling of Lepanthes eltoroensis in those populations; nevertheless it may be a slight over estimation.

The distribution of Lepanthes eltoroensis is not limited to a specific species of tree and a large number of tree species can be viable hosts. The orchid is preferentially distributed between 800 and $900 \mathrm{~m}$ above sea level. Low and high levels of light appear to affect population size of the orchid, suggesting that population size would be affected by the defoliation by hurricanes or by excess foliage growth by its hosts and surrounding trees.

Management of this species should include relocating orchids from felled trees onto new trees as soon as possible after a hurricane or random tree falls. Total number of Lepanthes eltoroensis orchid individuals is estimated to be in the range of the 3000 orchids, and since effective population size, of this species is likely $<20 \%$ (Tremblay \& Ackerman 2001), it is essential that management actions should maximize population size.

Acknowledgements. The author thanks all the people and students who have volunteered to collect data for this research: A. Gomez, J. Ramirez, B. Drapeau, P. Fuentes, P. Q. M. Figueroa, O. C. A. Rodríguez, C. Morales, R. B. Joubert, J. Paredes, L. N. Lopez, F. C. Arroyo, L. R. Esquilin, J. A. ColónSantiago, E. G. Ramos, J. C. Delgado, M. A. Pedroza, S. Flecha, N. R. Gomez, J. V. Castro and J. A. Colon; and Luis Rivera from Forest Service for the required permits as well as his support for this research.

\section{LITERATURE CITED}

Ackerman JD (1995) An orchid flora of Puerto Rico and the Virgin Islands. Mem N Y Bot Gard 73:1-208

Ackerman JD, Montalvo AM, Vera AM (1989) Epiphyte host specificity of Encyclia krugii, a Puerto Rican endemic orchid. Lindleyana 4:74-77

Agosto Pedroza MM, Tremblay RL (2003) El area fotosintética como indicador de la produccion de flores en Lepanthes sanguinea. Lankesteriana 7:65-66

Blanco M, Barboza G (2005) Pseudocopulatory pollination in Lepanthes (Orchidaceae: Pleurothallidinae) by fungus gnats. Ann Bot (Lond) 95:763-772

Fernández DS, Fetcher N (1991) Change in light availability following Hurricane Hugo in a subtropical montane forest in Puerto Rico. Biotropica 23:393-399

Fernández DS, Tremblay RL, Ackerman JD, Rodriguez E, López LN (2003) Reproductive potential, growth rate and light environment in Lepanthes rupestris Stimson. Lankesteriana 7:73-76

Lodge DJ, McDowell WH (1991) Summary of ecosystem effects of Caribbean hurricanes. Biotropica 23:373-378

Migenis LE, Ackerman JD (1993) Orchid-phorophyte rela- tionship in a forest watershed in Puerto Rico. J Trop Ecol 9:231-240

Rodríguez-Robles JA, Ackerman JD, Melendez EJ (1990) Host distribution and hurricane damage to an orchid population at Toro Negro, Puerto Rico. Caribb J Sci 26: 163-164

Ruiz-Canino F, Fernández DS, Melendez-Ackerman EJ, Tremblay RL (2007) The effect of the light environment on population size of the epiphytic herb, Lepanthes rupestris (Orchidaceae). Lankesteriana 7:357-361

Smith MJ, Sibly RM (2008) Identification of trade-offs underlying the primary strategies of plants. Evol Ecol Res 10:45-60

Sokal RP, Rohlf FJ (1981) Biometry: the principles and practice of statistics in biological research, 2nd edn. W. H. Freeman, New York

Tremblay RL (1997) Distribution and dispersion patterns of individuals in nine species of Lepanthes (Orchidaceae). Biotropica 29:38-45

Tremblay RL (2000) Plant longevity in four species of Lepanthes (Pleurothallidinae, Orchidaceae). Lindleyana 15: 257-266

Tremblay RL (2003) How low is too low? Fruiting success in Lepanthes species. In: Dixon K, Kell S, Barrett R, Cribb P (eds) Orchid conservation. Natural History Publications, Sabah, p 122-123

Tremblay RL, Ackerman JD (2001) Gene Flow and effective population size in Lepanthes (Orchidaceae): a case for genetic drift. Biol J Linn Soc 72:47-62

Tremblay RL, Ackerman JD (2003) The genetic structure or orchid populations and its evolutionary importance. Lankersteriana 7:87-92

Tremblay RL, Velazquez-Castro J (in press) Circular distribution of an epiphytic herb on trees in a subtropical rain forest. Tropical Ecol

Tremblay RL, Zimmerman J, Lebrón L, Bayman P, Sastre I, Axelrod F, Alers-García J (1998) Host specificity and low reproductive success in the rare endemic Puerto Rican orchid Lepanthes caritensis (Orchidaceae). Biol Conserv 85:297-304

> Tremblay RL, Ackerman JD, Zimmerman JK, Calvo R (2005) Variation in sexual reproduction in orchids and its evolutionary consequences: a spasmodic journey to diversification. Biol J Linn Soc 84:1-54

Tremblay RL, Pomales-Hernández G, Méndez-Cintrón ML (2006) Flower phenology and sexual maturation: analogous protandrous behaviour in three species of orchids. Caribb J Sci 42:75-80

Valladares F, Sanchez-Gomez D, Zavala MA (2006) Quantitative estimation of phenotypic plasticity: bridging the gap between the evolutionary concept and its ecological applications. J Ecol 94:1103-1116

Wang HCA, Hall S, Scatena FN, Fetcher N, Wu W (2003) Modeling the spatial and temporal variability in climate and primary productivity across the Luquillo Mountains, Puerto Rico. For Ecol Manag 179:69-94

You C, Petty WH (1991) Effects of Hurricane Hugo on Manilkara bidentata, a primary tree species in Luquillo Experimental Forest of Puerto Rico. Biotropica 23:400-406

Zimmerman JK (1991) Ecological correlates of labile sex expression in the orchid Catasetum viridiflavum. Ecology 72:597-608

Zimmerman JK, Olmstead IC (1992) Host tree utilization by vascular epiphytes in a seasonally inundated forest (tintal) in Mexico. Biotropica 24:402-407 